\title{
„WITAJCIE BEZDOMNI, LECZ DRODZY NAM BRACIA". POLSKIE OBOZY WOJSKOWE NA WĘGRZECH W CZASIE II WOJNY ŚWIATOWEJ
}

\begin{abstract}
Streszczenie. Po agresji ZSRR na Polskę, 17 września 1939 r., miejscem docelowym ewakuacji wielu polskich żołnierzy stał się obszar Królestwa Węgier. W 1939 r., pomimo współpracy z III Rzeszą, obywatele węgierscy podjęli bardzo duży wysiłek, aby pomóc Polakom przedostać się na teren Królestwa, a następnie wesprzeć ich na miejscu. Jesienią 1939 r. na terytorium Węgier znalazło się ponad 45000 polskich żołnierzy, którzy zostali rozmieszczeni w ok. 140 obozach. Większość z placówek powstała w ośrodkach miejskich oraz wiejskich, co w sposób zasadniczy wpłynęło na wygląd oraz strukturę organizacyjną oraz ludnościową miast i wsi. Biorąc ponadto pod uwagę liczbę uchodźców cywilnych, tak duża grupa polskiej ludności stanowiła dla władz węgierskich nie lada wyzwanie w zakresie relokacji Polaków i otoczenia ich opieką.
\end{abstract}

Zagadnienia poruszone $w$ artykule dotyczą organizacji polskich obozów dla internowanych żołnierzy na terenie Królestwa Węgier. Opisany został wpływ tych ośrodków na funkcjonowanie miast i wsi, ludność je zamieszkującą, jak i na samych Polaków, z których perspektywy pobyt na Węgrzech miał być rozwiązaniem tymczasowym.

Słowa kluczowe: uchodźstwo, Polacy na Węgrzech, internowanie, obozy wojskowe, II wojna światowa

Jesienią 1939 r., po ataku ZSRR na Polskę, Królestwo Węgier stało się miejscem docelowym dla ok. 45000 ewakuowanych polskich żołnierzy ${ }^{1}$. Po przekroczeniu granicy byli oni internowani - musieli oddać broń i udać się do utworzonych na potrzeby tej sytuacji obozów wojskowych. W związku z tym, że liczba

${ }^{1}$ I. LAGZI, Droga żotnierza polskiego przez wegierska granicę w latach 1939-1941, Poznań 1987, s. 293. 
uchodźców z Polski zaskoczyła Węgrów, część żołnierzy relokowano w głąb kraju, aby zrobić miejsce dla nowo przybyłych. Informacje dotyczące losów polskich uchodźców były szeroko opisywane w węgierskiej prasie ${ }^{2}$. Dlatego też mieszkańcy miast i wsi często gromadzili się na stacjach kolejowych lub przed wejściem do obozu, i witali przybywających Polaków. Ludność przygotowywała także transparenty z różnymi hasłami, np.: „Witajcie bezdomni, lecz drodzy nam bracia”. Przychylna postawa Węgrów i ich chęć pomocy była bardzo pozytywnie odbierana przez polskich uchodźców.

Przedmiotem analiz przedstawionych w niniejszym artykule jest wpływ polskich obozów wojskowych na funkcjonowanie węgierskich miast i wsi, na ludność je zamieszkującą oraz na samych Polaków, z których perspektywy pobyt na Węgrzech miał być rozwiązaniem tymczasowym.

\section{Stań badań}

Temat polskich uchodźców w Królestwie Węgier w czasie II wojny światowej został dość szczegółowo omówiony zarówno przez historyków polskich, jak i węgierskich ${ }^{3}$. W ich publikacjach szeroko opisano zagadnienia dotyczące m.in. przedostania się Polaków na terytorium Węgier jesienią 1939 r., formowania oraz funkcjonowania obozów wojskowych i cywilnych, roli organizacji pomagającym polskim obywatelom oraz losów uchodźców po agresji III Rzeszy na Królestwo Węgier w marcu 1944 r.

Warto jednak podkreślić, że stosunkowo znaczną grupę autorów publikacji na temat przyjaźni polsko-węgierskich i losów polskich uchodźców na Węgrzech w czasie II wojny światowej stanowią sami świadkowie historii, którzy chcieli upamiętnić swój pobyt w Królestwie Węgier. Część z nich poszerzyła podstawę źródłową swoich prac o materiały archiwalne czy badania naukowe. Za przykład mogą tu posłużyć książki Tibora i Heleny Csorbów, którzy przeprowadzili badanie socjologiczne za pomocą ankiet skierowanych do uchodźców ${ }^{4}$.

${ }^{2}$ K. Łuвсzyк, G. ŁubCzy к, Pamięć. Polscy uchodźcy na Wegrzech 1939-1946, t. 2, Warszawa 2012, s. 53.

${ }^{3}$ I. LAGZI, op. cit.; IDEM, Uchodźcy polscy na Wegrzech w latach II wojny światowej, Warszawa 1980; K. Kapronczay, Refugees in Hungary: Shelter from Storm During World War II, Toronto-Buffalo 1999; M. Wieliczko, Polacy na Wegrzech, Lublin 1977.

${ }^{4}$ H. Csorba, T. Csorba, Ziemia wegierska azylem Polaków: 1939-1945, Warszawa 1985. 
Wśród badaczy poszerzających wiedzę o losach polskich uchodźców na Węgrzech w czasie II wojny światowej są także osoby niezwiązane z dziedziną historii, ale z naukami pokrewnymi, m.in. literaturoznawca Krzysztof Woźniakowski . Bardzo cenne są także publikacje Krystyny i Grzegorza Łubczyków ${ }^{6}$.

\section{Podstawa źródłowa}

Autorka niniejszego artykułu w swoich badaniach korzystała ze źródeł znajdujących się w Archiwum Akt Nowych, Centralnym Archiwum Wojskowym oraz Archiwum Związku Nauczycielstwa Polskiego. Wśród analizowanych dokumentów znalazły się m.in. sprawozdania Amerykańskiej Komisji Pomocy Polakom (AKPP) z wizytacji polskich obozów wojskowych, korespondencja AKPP z obozami wojskowymi, kroniki i jednodniówki niektórych obozów.

Autorka korzystała także z wydanych w formie książkowej wspomnień, zarówno uchodźców polskich, jak i Węgrów ${ }^{7}$, a także z trzech albumów autorstwa Krystyny i Grzegorza Łubczyków, w których zostały zamieszczone dotychczas niepublikowane źródła oraz zdjęcia ${ }^{8}$.

\section{Wybuch II wojny światowej}

Początkową cezurą w historii polskiego uchodźstwa w Królestwie Węgier jest 17 września 1939 r., ponieważ po agresji ZSRR na Polskę duże grupy ludności (cywilnej i wojskowej) zaczęły przekraczać węgierską granicę. W obliczu zbliżającej się klęski kampanii wrześniowej wiele jednostek wojskowych otrzymało rozkaz przedostania się do innych krajów, aby następnie dotrzeć do Francji i tam formować polskie oddziały wojskowe.

${ }^{5}$ K. Woźnia Kowski, W kregużycia kulturalnego polskiego wojennego uchodżstwa na Wegrzech 1939-1945. Studia i szkice, Kraków 2018.

${ }^{6}$ K. ŁUвCZYк, G. ŁUвCZYк, op. cit., t. 1-2.

7 Wspomnienia polskich uchodźców na Wegrzech $w$ latach 1939-1945, red. J. STOLARSKI, Warszawa 1999.

${ }^{8}$ K. ŁUвCZYк, G. ŁUвCZYк, op. cit. 
Polscy żołnierze zostali ewakuowani na Litwę, Łotwę, Węgry i do Rumunii ${ }^{9}$. Jesienią 1939 r. na Litwie znalazło się ok. 140000 żołnierzy $^{10}$, na Łotwie ok. $1570^{11}$, na Węgrzech ok. $45000^{12}$, a w Rumunii ok. 24-25000 13 . Kraje te za podstawę swoich działań w stosunku do uchodźców wojskowych przyjęły postępowanie zgodne z konwencją haską z 1907 r. oraz konwencją genewską z 1929 r. ${ }^{14}$ Artykuły 11 i 12 konwencji haskiej zawierają instrukcje dotyczące internowania, rozlokowania oraz aprowizacji uchodźców. W konwencji genewskiej zostały ujęte kwestie dotyczące ewakuacji jeńców wojennych do obozów, organizacji, higieny i urządzenia pomieszczeń oraz budynków, w których internowani żołnierze mieliby zamieszkać. Ponadto dokument obejmuje zagadnienia związanie z odżywianiem, ubiorem oraz wypełnianiem potrzeb intelektualnych i moralnych jeńców wojennych.

Za wszelkie sprawy organizacyjne polskich uchodźców wojskowych odpowiedzialny był XXI Oddział Ministerstwa Honwedów, na którego czele stał płk Zoltán Baló. Funkcję przedstawiciela polskich żołnierzy w tej instytucji pełnił gen. Stefan Dembiński.

\section{Akcja „Ewa”}

Liczba internowanych żołnierzy na Węgrzech przez cały okres II wojny światowej (a właściwie do marca 1944) stale się zmieniała. Miało to przede wszystkim związek z organizowaną akcją „Ewa”, czyli ewakuacją polskich żołnierzy do Francji lub na Bliski Wschód.

Do kwietnia 1941 r. głównym miejscem ewakuacji była Jugosławia, skąd Polacy udawali się do innych krajów, w szczególności do Francji, a po jej kapitulacji w maju 1940 r. m.in. na Cypr i do Syriii ${ }^{15}$. Warte podkreślenia jest to,

9 Wysiedlenia, wypędzenia iucieczki 1939-1959: atlas ziem Polski: Polacy, Żydzi, Niemcy, Ukraińcy, red. W. Sienkiewicz, G. Hryciuk, Warszawa 2008, s. 32.

10 W.K. Roman, Ewakuacja i internowanie wojsk polskich we wrześniu 1939 roku, „Piotrkowskie Zeszyty Historyczne" 2004, t. 6, s. 166.

${ }^{11}$ Ibidem, s. 165.

12 I. Lagzi, Droga żotnierza..., s. 293.

13 W.K. Roman, op. cit., s. 168.

${ }^{14}$ Ibidem, s. 164.

15 I. LAGzi, Uchodźcy polscy..., s. 155. 
że zmieniająca się liczba uchodźców miała ogromny wpływ na rozmieszczenie oraz stan liczebny obozów. Był on bowiem redukowany, a żołnierze przenoszeni, np. jeńcy z obozu Sárvár po jego rozwiązaniu w kwietniu 1941 r. zostali przeniesieni do miejscowości Kiscenk ${ }^{16}$.

Z powodu zacieśniania się politycznej współpracy z Niemcami akcja „Ewa” była także problematyczna dla samych Węgrów, w których interesie nie leżało powiększanie wojsk alianckich o polskich uciekinierów z ich kraju. Wprowadzano różne restrykcje mające na celu uniemożliwienie Polakom dalszych ucieczek, np. starano się, aby internowani żołnierze znajdowali się w „zamkniętych” obozach - otoczonych murem lub ogrodzeniem, niekiedy z drutem kolczastym. Surowo karano zarówno złapanych uciekinierów, jak i osoby, które im pomagały. Część węgierskich komendantów obozów po udanej ucieczce lub jej próbie podwajała straże obozowe ${ }^{17}$. Jedną z często stosowanych kar w stosunku do złapanych żołnierzy było wysłanie ich do obozu karnego w Komárom, a po jego likwidacji do obozu karnego w Siklós ${ }^{18}$.

Mimo wprowadzonych obostrzeń uchodźcy szukali różnych sposobów, aby wydostać się z niektórych ośrodków, np. w obozie w Léva pewnej nocy uciekło 15 osób. Okazało się, że uciekinierzy uprzednio pospinali pasy od swoich mundurów i w ten sposób zeszli przez okno z pierwszego piętra na ulicę. W ramach kary wszyscy żołnierze musieli zdać swoje pasy węgierskiemu komendantowi ${ }^{19}$.

Warto zaznaczyć, że akcja „Ewa” nie mogłaby się odbyć bez wsparcia lokalnych mieszkańców, którzy pomagali w transporcie żołnierzy oraz w zorganizowaniu im ubrań cywilnych. Jak wspomina Węgier Zoltán Hodányi, który mieszkał w miejscowości Szombathely:

Polscy żołnierze chcieli, jak najszybciej, znaleźć się w państwach walczących z Hitlerem. Jedynym rozwiązaniem była tu ucieczka! A że w mundurach było to niemożliwe, zaczęliśmy gromadzić dla nich cywilne ubrania. Wiele osób dostarczyło do obozu odzież w znośnym stanie. Najwięcej pomagały proste rodziny, zamieszkałe w pobliżu ${ }^{20}$.

\footnotetext{
${ }^{16}$ K. ŁuвсZyк, G. ŁuвCZyк, op. cit., t. 2, s. 72.

${ }_{17}$ Wspomnienia..., s. 172.

18 Ibidem, s. 178.

19 Ibidem, s. 172.

${ }^{20}$ Ibidem, s. 165.
} 
Skalę akcji ewakuacyjnej obrazują liczby. Od 1942 do 1944 r. liczba polskich uchodźców wojskowych na Węgrzech utrzymywała się na stałym poziomie ok. 5600 żołnierzy ${ }^{21}$.

\section{Warunki zamieszkania}

Żołnierze po przekroczeniu granicy polsko-węgierskiej zostawali zazwyczaj podzieleni na trzy grupy - oficerów, podoficerów oraz szeregowych. Było to zgodne $\mathrm{z}$ węgierskim zwyczajem, wedle którego oficerów odseparowywano od swoich żołnierzy. W wielu wypadkach próba w prowadzenia takiego podziału, zgoła odmiennego od obowiązującego w wojsku polskim, wywoływała sprzeciw - zarówno oficerów, jak i szeregowych. W niektórych przypadkach po protestach, w szczególności grupy oficerów, udawało się uzyskać zgodę na nierozdzielenie, m.in. w 10 Brygadzie Kawalerii (zmotoryzowanej) ${ }^{22}$, ale i tak większość internowanych musiała dostosować się do wprowadzonych regut.

Warto podkreślić, że najlepsze warunki zamieszkania panowały w obozach oficerskich. Ośrodki te mieściły się m.in. w hotelach, dworkach, prywatnych willach, domach letniskowych, pałacach, pensjonatach. Ponadto część oficerów, którzy przybyli na Węgry z rodzinami, po otrzymaniu zgody mogła zamieszkać w domach miejskich lub wiejskich, oczywiście wynajmując pokój za opłatą. Tak było m.in. w obozie w Rákoscsabie ${ }^{23}$. Oficerowie mieli także dużo więcej swobody, np. mogli bez większych ograniczeń poruszać się po mieście, nawiązywać kontakty z miejscową ludnością oraz z węgierskimi oficerami, a także brać udział w wydarzeniach kulturalnych. Ich żołd był na tyle wysoki (w 1939 wynosił dla oficerów 4 pengő dziennie, a w 1943 wzrósł do 5 pengő $)^{24}$, że nie musieli podejmować pracy zarobkowej. Zarabiali więcej niż w niektórych przypadkach ludność węgierska. Jak wspomina podchorąży Jan Stolarski, który znalazł się w obozie

${ }^{21}$ I. Lagzi, Uchodźcy polscy..., s. 200.

22 J. MajKA, Internowanie 10. Brygady Kawalerii (zmotoryzowanej) na Wegrzech w 1939 roku, „Annales Universitatis Mariae Curie-Skłodowska. Sectio F” 2005, t. 60, s. 186.

${ }^{23}$ Centralne Archiwum Wojskowe, Wojskowe Biuro Historyczne (dalej: CAW WBH), Uchodźstwo polskie na Węgrzech (dalej: Uch. Pol. Węg.), sygn. II.31.32, s. 7.

${ }^{24}$ I. LAGZI, Uchodźcy polscy..., s. 259, 272. 


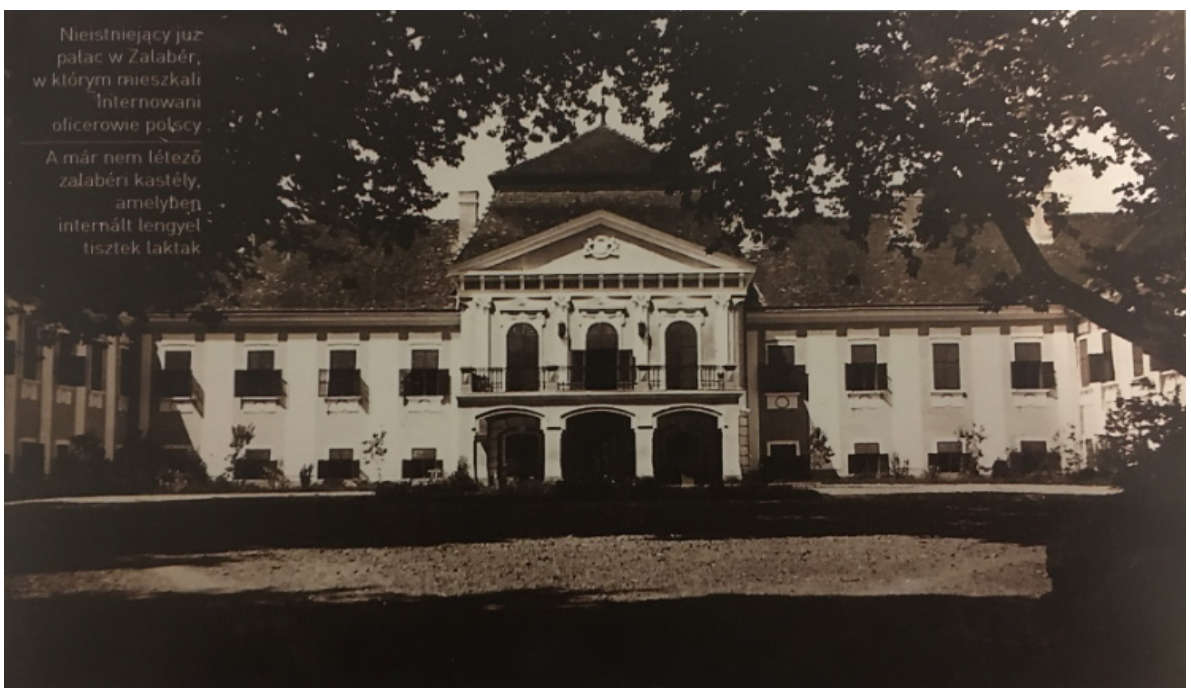

Ryc. 1. Pałac w Zalabér, w którym mieścił się obóz dla polskich oficerów (źródło: K. ŁuBczYK, G. ŁuBczYк, Pamięć. Polscy uchodźcy na Węgrzech 1939-1946, t. 2, Warszawa 2012, s. 235)

w Vámosmikoli, podczas gdy polski oficer otrzymywał 120 pengő miesięcznie, średnia pensja węgierskiego nauczyciela na wsi wynosiła 60-80 pengo" ${ }^{25}$.

Za przykład obrazujący bardzo dobre warunki zamieszkania w obozach oficerskich może posłużyć poniższe zdjęcie pałacu w Zalabér. Był tam dostęp do bieżącej wody i centralnego ogrzewania. Oficerowie mogli także swobodnie spacerować po parku, w którym znajdował się obóz ${ }^{26}$.

Poza dobrymi warunkami zamieszkania w obozach starano się rozbudowywać bądź stworzyć infrastrukturę sportową. W ośrodku w Rákoscsabie powstało boisko do gry w siatkówkę, była sekcja ping-ponga, korzystano też z pobliskiego basenu ${ }^{27}$.Kolejnym istotnym elementem obozów oficerskich były kasyna, gdzie polscy i węgierscy oficerowie mieli możliwość integracji.

Oczywiście, warunki zamieszkania w obozach oficerskich nie były zawsze tak dobre, jak w obozie w Zalabér czy Rákoscsabie (gdzie żołnierze mieszkali w dwustuletnim kasztelu). Za przykład może posłużyć obóz w Dömsöd, dokąd w 1942 r. zostali przeniesieni żołnierze z obozu z Rákocsaby. Polacy mieszkali tam w: „6 wspólnych kwaterach, położonych w różnych punktach bardzo

\footnotetext{
25 Wspomnienia..., s. 258.

26 K. ŁuвCZYк, G. ŁuвCZYк, op. cit., t. 2, s. 144.

27 CAW WBH, Uch. Pol. Węg., sygn. II.31.32, s. 8.
} 
rozległej wsi. Na sali mieszka przeciętnie 4-6 oficerów"28. Dość dużym problemem, z którym próbowano sobie poradzić w Dömsöd, były pluskwy gnieżdżące się na łóżkach i innych meblach w obozowym ambulatorium. Z braku nafty oraz innych środków dezynfekcyjnych żołnierze użyli maszyny, z której rzeźnicy korzystali do opalania szczeciny na zabitych świniach, a następnie umyli meble gorącą wodą z tugiem ${ }^{29}$.

Za kolejny przykład może posłużyć obóz dla oficerów w Selyp, który we wspomnieniach przez płk. Jana Korkozowicza został nazwany „najgorszym obozem na Węgrzech"30. Oficerowie mieszkali w betonowym, pofabrycznym budynku, wcześniej przeznaczonym dla pracowników sezonowych cukrowni w Selyp. Jak wspomina ppłk Włodzimierz Gilewski:

Pierwsze piętro budynku podzielone było na dwie sale sypialne po 70 łóżek piętrowych każda, na parterze zaś mieściła się świetlica - jadalnia, kantyna, sypialnia dla szeregowych oraz pomieszczenia gospodarcze. Urządzenia żadnego oprócz stołów i ław w jadalni, a łóżek i taboretów w sypialni - nie było. Prymityw absolutny. Z braku szaf trzymali oficerowie cały swój dobytek w walizkach pod łóżkami ${ }^{31}$.

W dużo gorszej sytuacji znaleźli się podoficerowie i szeregowi, ich obozy organizowano bowiem m.in. w koszarach wojskowych, zabudowaniach fabrycznych, zamkach czy barakach dawnej węgierskiej straży granicznej. Warunki zamieszkania w tych ośrodkach były skrajnie różne.

Część z obozów była bardzo dobrze przygotowana do przyjęcia uchodźców. Wszyscy mieli na czym spać - nawet jeśli nie było wystarczającej liczby łóżek, żołnierze otrzymywali sienniki - oraz gdzie jeść - w obozie organizowano kuchnię polową lub korzystano z usług lokalnej ludności np. obóz znajdujący się w miejscowości Jolsva. Inspektor wizytujący placówkę w kwietniu 1940 r. zapisał: „Żołnierze śpią na pryczach, na siennikach, częściowo na słomie na ziemi i posiadają prześcieradła. Na sali 4-18 osób - na ogół luźno. (...) Łaźnia i pralnia na miejscu. Umywalnie i ustępy skanalizowane"32.

${ }^{28}$ CAW WBH, Uch. Pol. Węg., sygn. II.31.32, s. 58.

${ }^{29}$ CAW W BH, Uch. Pol. Węg., sygn. II.31.32, s. 57.

${ }^{30}$ Wspomnienia..., s. 229.

${ }^{31}$ Ibidem, s. 229.

32 Archiwum Akt Nowych (dalej: AAN), Organizacje pomocy Polakom i instytucje polskie na Węgrzech (dalej: Org. Pom. Pol.), Amerykańska Komisja Pomocy Polakom na Węgrzech (dalej: AKPP), sygn. III/81, k. 140. 
Niestety zdarzały się także zgoła odmienne przypadki i występowały ogromne problemy aprowizacyjne. Brakowało miejsc do spania, mebli (w tym łóżek - żołnierze musieli spać na siennikach albo na słomie) czy ogrzewania. Za przykład posłużyć może obóz wojskowo-policyjny w Inárcs. W styczniu 1940 r. przebywały tam łącznie 384 osoby (oficer lekarz, 108 policjantów, 25 urzędników wojskowych i 250 szeregowych ${ }^{33}$. Według arkusza inspekcyjnego obozu, wypełnionego przez przedstawiciela AKPP, warunki w ośrodku nie były dobre: „Szeregowi i urzędnicy wojskowi mieszkają w zamku po około 30-stu w izbie, policja mieszka w 2-ch oficynach folwarcznych na salach od 17-stu do 52-ch ludzi. Świetlenie naftowe - skąpe" ${ }^{\text {"34 }}$. Ponadto mieszkańcy obozu spali na słomie, a łaźnia w zamku nie spełniała wystarczająco swoich funkcji. Brakowało pomieszczenia na świetlicę. Wśród rzeczy wymienionych jako potrzebne internowanym znalazły się m.in. ciepła bielizna, mydło, leki, zeszyty, pieniądze na naftę, stoły i lawy ${ }^{35}$.

W jeszcze gorszej sytuacji byli mieszkańcy obozu w Magyaróvár, gdzie znalazło się 718 osób rozlokowanych w nieczynnej fabryce (1 km od miasta) oraz w nieczynnym browarze (w mieście). W sprawozdaniu warunki zamieszkania zostały opisane jako tragiczne. Jak można przeczytać w raporcie: „Spanie więcej jak fatalne, prycz nie ma. Pralni, łazienki i ubikacji nie ma. (...) Świetlicy nie ma. (...) Największą potrzebą obozu są prycze i opal”" ${ }^{\prime 36}$ W dalszej części raportu wskazano także: „z sufitu odlatuje tynk i kapie wilgoć tak, że kilkakrotnie nocą [mieszkańcy] muszą przenosić barłogi z miejsca na miejsce. Ich spanie i przebywanie absolutnie nie różni się od spania na dworzu [!], gdyż mimo otrzymanych większych racji węgla lokale są jakby nieopalone" ${ }^{\text {37 }}$. Osoba dokonująca inspekcji zasugerowała zamknięcie obozu: „Celem zaoszczędzenia dużych inwestycji najlepiej by było najrychlejsze zlikwidowanie" 38 .

Podobne warunki panowały w obozie wojskowym w Komárom. Z arkusza inspekcyjnego wynika, że: „Internowani pomieszczeni sąw jednym z fortów oraz w starej stajni. Warunki kwaterunkowe straszne. Zimno, wilgoć, brak pryczy,

\footnotetext{
${ }^{33}$ AAN, Org. Pom. Pol., AKPP, sygn. III/81, k. 137.

${ }^{34}$ AAN, Org. Pom. Pol., AKPP, sygn. III/81, k. 137.

${ }^{35}$ AAN, Org. Pom. Pol., AKPP, sygn. III/81, k. 137.

36 AAN, Org. Pom. Pol., AKPP, sygn. III/81, k. 139.

${ }^{37}$ AAN, Org. Pom. Pol., AKPP, sygn. III/81, k. 139.

${ }^{38}$ AAN, Org. Pom. Pol., AKPP, sygn. III/81, k. 139.
} 
spanie na cienkiej warstwie słomy" ${ }^{39}$. Tu także zarekomendowano, aby przenieść wszystkich internowanych do obozów o lepszych warunkach zamieszkania.

Próbowano rozwiązywać pojawiające się problemy. Funkcjonowanie ułatwiać miało tworzenie w obozach warsztatów stolarskich w celu budowy mebli i przeprowadzania innych niezbędnych prac budowlanych. AKPP wysyłała sprzęt do różnych ośrodków. Warsztaty stolarskie powstawały m.in. w Magyaróvár czy Kisbodak. Żołnierze remontowali także pomieszczenia. W kronice czasopisma „Nasze Życie”, wydawanym w obozie Bregenc-Major przez polskich żołnierzy, zamieszczono notatkę:

Podziwialiśmy niedawno kuchenkę wybudowaną na sali podoficerskiej zwanej „Ochronką", podobna kuchenka została wybudowana w baraku „Willa Nędza" kompania 4. Prawdziwe uznanie należy się PP. podoficerom za doprowadzenie do porządnego wyglądu zewnętrznej części budynku mieszczącego „Ochronkę", a także za wybudowanie przedsionka, który niewątpliwie ociepli mieszkanie ${ }^{40}$.

Poza samymi warunkami mieszkaniowymi duże znaczenie miało położenie geograficzne obozu, tzn. czy znajdował się on w mieście, na jego obrzeżach, na wsi, czy był znacznie oddalony od jakiegokolwiek ośrodka. W liście do AKPP starszy obozu Internowanych Oficerów Polski w miejscowości Ipolyszalka, ppłk. Tadeusz Kosiński zawarł prośbę o przydział piłki siatkowej, sprzętu do gry w koszykówkę, większej liczby instrumentów muzycznych oraz literatury naukowej dotyczącej wojska i najnowszych zmian w uzbrojeniu i taktyce. Kosiński motywował swą prośbę tym, że:

obóz tutejszy w odróżnieniu od innych obozów, pomieszczony jest od lat trzech na głuchej wsi, z dala od kolei i wszelkich kulturalnych rozrywek, których dostarczyć może innym obozom miasto, zasługuje na specjalne uwzględnienie i pomoc przy zorganizowaniu sobie choćby namiastki życia kulturalnego na miejscu ${ }^{41}$.

39 AAN, Org. Pom. Pol., AKPP, sygn. III/81, k. 135.

40 „Nasze Życie - czasopismo żołnierzy polskich internowanych w Królestwie Węgier” 1941, nr 12, s. 7.

${ }^{41}$ Archiwum Związku Nauczycielstwa Polskiego (dalej: ZNP), Komisja do Badania Dziejów Oświaty i Wychowania (dalej: Kom. Bad. Dz. Ośw.), sygn. 127, k. 122. 


\section{Wpływ obozów na funkcjonowanie węgierskich ośrodków miejskich i wiejskich}

Bez wątpliwości można stwierdzić, że pojawienie się obozów dla internowanych żołnierzy w ośrodkach miejskich i wiejskich wpływało w większym lub mniejszym stopniu na funkcjonowanie węgierskich miast i wsi. Oczywiście, zakres tego wpływu zależał od kilku czynników, m.in. charakteru danego obozu, tzn. liczby internowanych oraz przychylności władz obozowych wobec Polaków lub jej braku. W niektórych ośrodkach nie istniała możliwość opuszczenia obozu bez uzyskania przepustki. W tym aspekcie zdecydowanie bardziej uprzywilejowane były obozy oficerskie, gdzie w wielu przypadkach żołnierze mieli całkowitą swobodę w odwiedzaniu pobliskich miejscowości. Wprowadzanie zakazu wychodzenia poza teren ośrodka było także pewną formą zbiorowej kary, np. za podjęcie próby ucieczki lub udaną ucieczkę z obozu.

Niewątpliwie obecność Polaków w węgierskich miastach czy wsiach prowadziła do wymiany z miejscową ludnością zarówno w aspekcie kulturowymi, jak i materialnym. W dalszej części artykułu zostanie zaprezentowany wpływ polskich uchodźców na pewne wymiary życia ludności węgierskiej, tj. handel, rynek pracy, czas wolny, kulturę, religię oraz relacje międzyludzkie.

\section{Handel}

W wielu ośrodkach miejskich oraz wiejskich przybycie Polaków przyczyniło się do rozwoju handlu. Uchodźcy mogli wydać w pobliskich miejscowościach otrzymany żołd czy zarobione pieniądze, na czym zdecydowanie korzystała lokalna ludność. W swoich wspomnieniach uchodźcy opisywali, że chodzenie na zakupy do miasta w czasie wolnym było czymś zwyczajnym ${ }^{42}$.

Żołnierze wydawali pieniądze nie tylko w sklepach, ale także w karczmach. Pchor. Jan Stolarski wspominał, że w miejscowości Vámosmikola znajdowały się trzy karczmy i w każdej z nich obiady jadali polscy oficerowie, ponieważ nie przysługiwały im posiłki w obozie ${ }^{43}$. Węgrzy prowadzili też działania handlowe na terenie ośrodków dla internowanych żołnierzy. Olexa Jósefne, mieszkanka Vámosmikola, w swoich wspomnieniach pisała, że rodzina Hiró podjęła się

\footnotetext{
42 Wspomnienia..., s. 263.

43 Ibidem, s. 258.
} 
prowadzenia stołówki w obozie, a matka z synem rozpoczęli nawet naukę języka polskiego, aby móc się porozumieć z polskimi żołnierzami ${ }^{44}$. Wymiana dóbr miała charakter dwustronny. Olexa Jósefne zanotowała, że większość oficerów z Vámosmikola sprzedała swoje mundury, za co otrzymała pieniądze oraz ubrania cywilne, a Węgrzy przerobili zakupione mundury na płaszcze i jesionki dla siebie $^{45}$.

O dużym znaczeniu handlu z uchodźcami dla węgierskiej ludności świadczy historia opisana przez Józefa Muniaka z miejscowości Hőgyes. W związku z licznymi ucieczkami Polaków z obozu podjęto decyzję o zmianie węgierskiego komendanta na bardziej rygorystycznego, który po objęciu stanowiska m.in. cofnął wszystkie przepustki oraz zezwalał na opuszczenie obozu tylko w szczególnych i uzasadnionych przypadkach, ale pod eskortą żołnierzy ${ }^{46}$. Decyzje te spowodowały, że Polacy przestali odwiedzać miasto, a mieszkańcy Hőgyes, choć jak wskazuje autor, sami (będąc potomkami Niemców osiedlonych tam 100 lat wcześniej) byli nieprzychylnie nastawieni do Polaków, sprzeciwiali się wprowadzonym zmianom ${ }^{47}$. Jak pisał internowany Józef Muniak, decyzje komendanta doprowadziły do zastoju w handlu:

Istotnie miejscowi hitlerowcy pisali skargi do Ministerstwa Honwedów na obu poprzednich komendantów naszego obozu, Węgrów, zarzucając im spoufalanie i przyjaźnienie się z Polakami i rozpuszczanie ich. Ale i na kapitana Górskiego także poszły skargi i to pisane tą samą ręką, co na jego poprzedników. Oskarżono go o wręcz przeciwne postępowanie: zarzucano mu, że trzyma Polaków zbyt ostro, że nie wypuszcza ich na miasto i dlatego w Hőgyes zamarł cały handel ${ }^{48}$.

Kolejnym przykładem potwierdzającym znaczenie handlu z uchodźcami jest obóz w Eger, gdzie władze miasta interweniowały w sprawie pomysłu likwidacji obozu. Jak wspomina por. M. Kaliński:

Były liczne wypadki zapowiedzi zlikwidowania obozu w Egerze, lecz nie doszły do skutku, zdaje się wskutek usilnych starań miasta u właściwych czynników wojskowych. Miastu bardzo zależało na tym, by obóz w Egerze istniał. Pomijając bowiem względy uczuciowej sympatii, przemawiał za tym interes gospodarczy.

\footnotetext{
${ }^{44}$ Ibidem, s. 265.

45 Ibidem, s. 268.

46 Ibidem, s. 225.

47 Ibidem, s. 224.

48 Ibidem, s. 226.
} 
Sama bowiem gmina czerpie z uchodźców znaczne dochody z dzierżawy budynków miejskich na kwatery. Jest to dochód znaczny, stały i pewny. Po wtóre wielu uchodźców zajmuje kwatery prywatne, z czego czerpią dochody właściciele domów i mieszkań. W końcu najbardziej zarabiają na uchodźcach kupcy, gdyż wszystkie pieniądze przechodzą z kieszeni internowanych do kas kupieckich ${ }^{49}$.

Węgrzy zarabiali więc, prowadząc sklepy, karczmy, knajpy, wynajmując pomieszczenia. Niektórzy uchodźcy, najczęściej oficerowie, wybierali bowiem wynajmowanie kwatery w mieście niż pozostanie w obozie. Część mieszkań była także wynajmowana przez władze gminy dla uchodźców, co także przynosiło miastu spore dochody.

\section{Rynek pracy}

Kolejnym obszarem, w którym nastąpiły zasadnicze zmiany z uwagi na obecność Polaków, był rynek pracy. Uchodźcy, w szczególności szeregowi, podejmowali się pracy u miejscowej ludności. Wynikało to przede wszystkim z niskiego żołdu, który otrzymywali. W 1939 r. wynosił on dla szeregowych 20 fillerów dziennie, a w 1943 r. wzrósł do 40 fillerów ${ }^{50}$. Ponadto potrzeby uchodźców były także zbieżne z potrzebami Węgrów, którzy musieli zatrudnić więcej pracowników do pracy na polu, aby m.in. zdążyć z dostawą artykułów rolniczych do III Rzeszy ${ }^{51}$. Uchodźcy bardzo często brali udział w pracach sezonowych, np. na roli, w lesie, w winnicach, ale także w fabrykach (z wyłączeniem fabryk broni), przy regulacji rzek (Zsitra) czy kopaniu kanałów ${ }^{52}$. Pracowali także w kamieniołomach i tartakach. O tym, że podejmowanie pracy zarobkowej było czymś powszechnym, świadczy fakt, że w 1943 r. 85\% internowanych szeregowych pracowało zarobkowo.

Warto zaznaczyć, że praca u Węgrów generowała czasem konflikty, np. gdy pracodawca nie chciał zapłacić za wykonaną pracę. Taką historię opisuje kpr. Edward Zgórka, który pracował w lesie i przebywał w miejscowości Pelsőe. Jak pisze:

\footnotetext{
49 Wspomnienia..., s. 179.

50 I. LAGzI, Uchodźcy polscy..., s. 259, 272.

51 Ibidem, s. 226.

52 Wspomnienia..., s. 207.
} 
Po trzech tygodniach pracy zwróciliśmy się do naszego szefa o jakąś wypłatę, a przynajmniej zaliczkę. Pan szef udał się więc w tej sprawie do leśniczego i kiedy wrócił, okazało się, że summa summarum nam trzeba jeszcze dopłacić za życie, ponieważ więcej żeśmy przejedli, jak zarobili. (...) Wiadomość szefa zrobiła jednak bardzo złe wrażenie, wszyscy się naraz zbuntowali. Wszyscy zaczęli krzyczeć, więcej nie pracujemy, niech nas odwiezie do obozu, nawet do karnego, byleby tu już $\mathrm{z}$ tą pracą raz skończyćc ${ }^{53}$.

Dlatego też Ministerstwo Honwedów pod koniec 1942 r. wydało rozporządzenie dotyczące zasad zatrudniania uchodźców polskich, zgodnie z którym mogli być oni przyjęci do pracy tylko poprzez podanie złożone przez pracodawcę do komendanta obozu. Umowa była zawierana między komendą obozu a pracodawcą. W rozporządzeniu znajdowały się szczegółowe ustalenia dotyczące kwestii związanych z zatrudnieniem.

\section{Czas wolny}

Obecność Polaków wpływała także na sposób spędzania czasu wolnego przez Węgrów. Aktywności uchodźców w czasie wolnym od pracy i innych obowiązków zależały od kilku czynników, m.in. od położenia obozu (w mieście, na wsi lub z dala od jakiegokolwiek ośrodka), od zarobków lub wysokości żołdu, a także od infrastruktury obozu i okolicznych miejscowości. Bardzo ważnym czynnikiem była także forma organizacji obozu: otwarta lub zamknięta, co determinowało kontakty z lokalną ludnością. Gdy żołnierze znajdowali się w obozie otwartym, który mogli opuszczać bez przepustek, bardzo często korzystali z tej możliwości i odwiedzali pobliskie ośrodki miejskie lub wiejskie. Oczywiście sposób spędzania wolnego czasu różnił się w przypadku oficerów, podoficerów czy szeregowych.

Popularnymi miejscami spędzania wolnego czasu przez oficerów były kasyna, gdzie polscy żołnierze integrowali się z węgierskimi. W raportach AKPP pojawiała się informacja o istnieniu lub braku tego budynku w obozie, co świadczy o tym, że kasyna odgrywały istotną rolę w życiu internowanych. Funkcjonowały one w wielu obozach, m.in. w Kisbodak, Rákoscsabie, Dömsöd, Nagykanizsa, Jolsva, Selyp czy Hidasznémeti. W budynkach tych organizowano także ważne wydarzenia, m.in. obchody świąt dla całego obozu oraz wykłady czy warsztaty.

\footnotetext{
53 CAW WBH, Uch. Pol. Węg., sygn. II.31.24, k. 57.
} 
Tutaj też niektórzy oficerowie spożywali posiłki. O dużym znaczeniu tego miejsca dla społeczności obozowej można przeczytać w jednodniówce obozu w Rákoscsabie: „Kasyno wyposażone w dzienniki, pisma periodyczne, szereg gier towarzyskich itp. jest ośrodkiem życia kulturalno-towarzyskiego internowanych oficerów i ich rodzin" ${ }^{\prime 4}$.

Polscy oficerowie integrowali się z węgierskimi, biorąc udział we wspólnych polowaniach czy biesiadach ${ }^{55}$. Dużo wolnego czasu spędzali także w pobliskich miejscowościach. W Vámosmikoli według wspomnień pchor. J. Stolarskiego: „Oficerowie mogli wychodzić i wchodzić na wieś bez asysty, o ile nie było karnych zamknięć obozu. Najczęściej odwiedzanym gremialnie miejscem była bezpłatna plaża i kąpielisko nad rzeką Ipoly" ${ }^{\text {56 }}$. W tych samych wspomnieniach mowa też o robieniu zakupów: „Po obiedzie był czas wolny. Wówczas cała wieś ożywiała się. Wszędzie nas było pełno. Wszystkie sklepy we wsi, a było ich siedem, były zapełnione. Najwięcej kupujących było w sklepie, gdzie sprzedawano gazety, książki i artykuły piśmienne" ${ }^{57}$.

Oficerowie decydowali się także na podjęcie pracy. Jak wspomina pchor. J. Stolarski: „Kilkunastu z nich pracowało w gospodarstwach wiejskich, kilku u miejscowego piekarza, a jeden w spółdzielni szewskiej. Technik dentystyczny Ludwik Wisbain, członek obozu, uruchomił we wsi dentystyczny punkt przyjęć. Za swe usługi nie brał zapłaty, a mieszkańcy wsi pokrywali tylko koszty materiałów”58. Jak zapamiętała Olexa Józsefne, mieszkanka Vámosmikoli: „Polscy oficerowie rozeszli się po węgierskich domach i wkrótce w każdej prawie rodzinie znalazł się jakiś zadomowiony Polak. Chętnie pomagali w wielu pracach polowych, przy doglądaniu bydła, byle tylko nie spędzać dni na bezczynnym siedzeniu w obozie"59.

Oficerowie korzystali z dostępnej infrastruktury obozowej. Bardzo dobrym przykładem jest obóz w Eger, mieszczący się w budynkach zakładów kąpielowych, z których mogli korzystać uchodźcy w czasie wolnym, m.in. z basenu kąpielowego $z$ gorącą wodą mineralną ${ }^{60}$.

\footnotetext{
${ }^{54}$ CAW W BH, Uch. Pol. Węg., sygn. II.31.24, k.10.

55 I. LAGzI, Uchodźcy polscy..., s. 114.

${ }^{56}$ Wspomnienia..., s. 263.

57 Ibidem, s. 259.

58 Ibidem.

59 Ibidem, s. 268.

${ }^{60}$ Ibidem, s. 181.
} 
Podoficerowie i szeregowi, jeśli było to tylko możliwe, odwiedzali pobliskie miejscowości oraz brali udział w lokalnych wydarzeniach, np. w odpustach. Nawiązywali także relacje z miejscową ludnością. Jak wspomina Jan Żyromski z obozu Bregenc-Major:

Korzystając z przepustki niedzielnej, udaję się do mej znajomej zaraz w następną niedzielę. Poznaję rodziców i rodzeństwo, którzy, jak to dobrze... nie rozumieją niemieckiego języka. Od tego czasu odwiedziny swe na skutek zaproszeń oczywiście ponawiam, a czynię to chętnie, bo gdzież mógłbym spędzać tak miłe, długie niedzielne popołudnie i zjadać całe góry pysznych kołaczy, makowca i innych węgierskich przysmaków, jak nie u mojej znajomej! ${ }^{11}$

Żołnierze spędzali także czas wolny w obozie, m.in. grając w siatkówkę. Zachowały się nawet zdjęcia z obozu z Sárvár, przedstawiające grających uchodźców ${ }^{62}$.

Niemniej jednak nie we wszystkich obozach istniała taka możliwość. W sprawozdaniu z wizytacji obozu w miejscowości Léva wynika: „Internowani mieszkają w śródmieściu, w budynku ściśle izolowanym (okna zakratowane), przy czem pozbawieni są wolności. Jedynie oficerowie 2 razy w tygodniu chodzą na spacery w godzinach 8.00-11.00 rano w grupach po 20-ty pod ścisłą eskortą"63.

Ponadto na formę spędzania czasu wolnego i kontakty z ośrodkami miejskimi i wiejskimi miało wpływ położenie geograficzne obozu. Płk Jan Korkozowicz wspomina obóz w Selyp:

Piętrowe łóżka, braki w sprzęcie koszarowym, brak atrakcyjnego otoczenia na zewnątrz obozu (obok znajdowała się jedynie cukrownia produkująca... karabiny) i wieś Lőrinci, wszystko to stwarzało warunki niezbyt ciekawe. Zorganizowano zajęcia oświatowe w świetlicy (kasynie), z wiosną zaczęto uprawiać ogrodnictwo, zielarstwo, jedwabnictwo ${ }^{64}$.

\footnotetext{
${ }^{61}$ Ibidem, s. 233.

${ }^{62}$ K. ŁuвсZук, G. ŁUвсZук, op. cit., t. 2, s. 118.

${ }^{63}$ AAN, Org. Pom. Pol., AKPP, sygn. III/81, k. 142.

${ }^{64}$ Wspomnienia..., s. 229.
} 


\section{Religia}

Obecność polskich uchodźców wpłynęła również na działalność węgierskich księży, którzy starali się pomóc Polakom oraz nawiązywali kontakty z polskimi duchownymi. Kwestia wiary była dla większości internowanych żołnierzy niezwykle ważna. Ponadto władze węgierskie miały obowiązek, zgodnie z artykułem 16 rozdziału 4 konwencji genewskiej z 1929 r. zapewnić swobodę praktyk religijnych. Podczas II wojny światowej obecność polskich żołnierzy w niedzielę na mszach była czymś powszechnym. Brali oni udział w uroczystościach w pobliskich kościołach lub urządzali msze polowe w obozach, np. w Sárvár ${ }^{65}$. We wspomnieniach wielu uchodźców podkreślało, że zbiórki na wyjście do kościoła były najbardziej liczne ${ }^{66}$. Dla niektórych stanowiło to pewnie swego rodzaju rozrywkę. Potwierdzają to wspomnienia ppłk. Włodzimierza Gilewskiego z obozu w Selyp: „Jedyną rozrywką w dni powszednie był spacer po dużym podwórzu - ogrodzie, obramowanym wysokim płotem z drutu kolczastego, a w niedzielę wymarsz czwórkami pod eskortą do kościoła"67.

Warto także podkreślić przychylność i pomoc lokalnego węgierskiego duchowieństwa. W kościołach organizowano specjalne msze dla Polaków, m.in. w miejscowości Vámosmikola o godzinie 9.00 odbywała się msza dla uchodźców, a o 10:00 dla miejscowej ludności, która czasem przyłączała się do ceremonii dla Polaków ${ }^{68}$. Zdarzało się również, że księża odmawiali modlitwy w dwóch językach, np. w Nagykanizsy ${ }^{69}$. W duże zdumienie wprawił polskich żołnierzy węgierski ksiądz z Szombathely, który po mszy odczytał kazanie po polsku. Jak wspomina w swoim dzienniku plut. Adam Krawczyk:

Godzina 9.30: cały nasz obóz, czyli 1200 osób, idzie do kościoła. Pierwszy raz byliśmy na nabożeństwie w węgierskim kościele. W czasie mszy śpiewaliśmy polskie pieśni kościelne. Po mszy ksiądz odczytał po polsku jakby kazanie. Brzmiało bardziej po czesku niż po polsku, ale i tak byliśmy pod wrażeniem ${ }^{70}$.

\footnotetext{
65 K. ŁubCZyк, G. ŁUвCZyк, op. cit., t. 2, s. 122.

${ }^{66}$ Wspomnienia..., s. 134.

67 Ibidem, s. 229.

68 Ibidem, s. 267.

69 Ibidem, s. 240.

70 K. ŁuвCZyк, G. ŁubCzyк, op. cit., t. 2, s. 228.
} 
Polscy uchodźcy pozostawili po sobie liczne pamiątki będące dowodem wdzięczności dla Węgrów za ich pomoc. W większości miały one charakter religijny. Były to m.in. kapliczki (w Rákocsabie ${ }^{71}$ ), świeczniki (w Zalabér) ${ }^{72}$, kropielnice (w Zalaszentgrót $\left.{ }^{73}\right)$, tablice pamiątkowe (Sárvár $\left.{ }^{74}\right)$, obrazy Matki Boskiej (w Sopron ${ }^{75}$ ).

\section{Kultura}

Zacieśnienie więzi pomiędzy Węgrami a przebywającymi w obozach Polakami miało także swój aspekt kulturowy, zaczęto bowiem organizować wspólne wydarzenia i obchody świąt. Przygotowywano uroczystości, akademie i apele, w których brali udział przedstawiciele władz węgierskich oraz miejscowa ludność. Polacy obchodzili zarówno święta polskie, jak i węgierskie, m.in. 11 listopada 1941 r. w Zalaszengrót składano wieńce pod pomnikiem Węgrów poległych w I wojnie światowej ${ }^{76}$, a w dniu imienin Horthiego zorganizowano mszę oraz akademię w obozie w Bregenc ${ }^{77}$. W obozie Zalaszengrót pomiędzy 2 lipca 1940 a 31 grudnia 1941 r. „odprawiono specjalne nabożeństwa z okazji rocznic polskich (17) i węgierskich (4), z okazji obchodów narodowych świąt polskich (9) i węgierskich (2)"78. W styczniu 1940 r. w miejscowości Vámosmikola Polacy zorganizowali w domu kultury bal karnawałowy, w trakcie którego m.in. uczyli mieszkańców wsi tańczyć krakowiaka, mazurka i polki, a Węgrzy Polaków - czardasza ${ }^{79}$.

Uchodźcy organizowali także zawody - 10 października 1943 r. odbył się turniej szachowy pomiędzy Węgierskim Klubem Szachowym a reprezentacją polskiego obozu z Magyarbóly w Villány ${ }^{80}$. Wydarzenie to zostało uwiecznione na poniższym zdjęciu.

${ }^{71}$ CAW WBH, Uch. Pol. Węg., sygn. II.31.32, s. 1.

72 K. ŁuвCZyк, G. ŁUBCZYк, op. cit., t. 2, s. 102.

73 Wspomnienia..., s. 245.

${ }^{74}$ K. Łuвсzyк, G. ŁubCzyк, op. cit., t. 2, s. 127.

75 Ibidem, s. 413.

${ }^{76}$ Ibidem, s. 156.

77 „Nasze Życie - czasopismo żołnierzy polskich internowanych w Królestwie Węgier” 1941, nr 16, s. 8 .

78 K. ŁUвсzук, G. ŁUвсZук, op. cit., t. 2, s. 150.

79 Wspomnienia..., s. 273.

${ }^{80}$ CAW WBH, Uch. Pol. Węg., sygn. II.31.24, k. 57. 


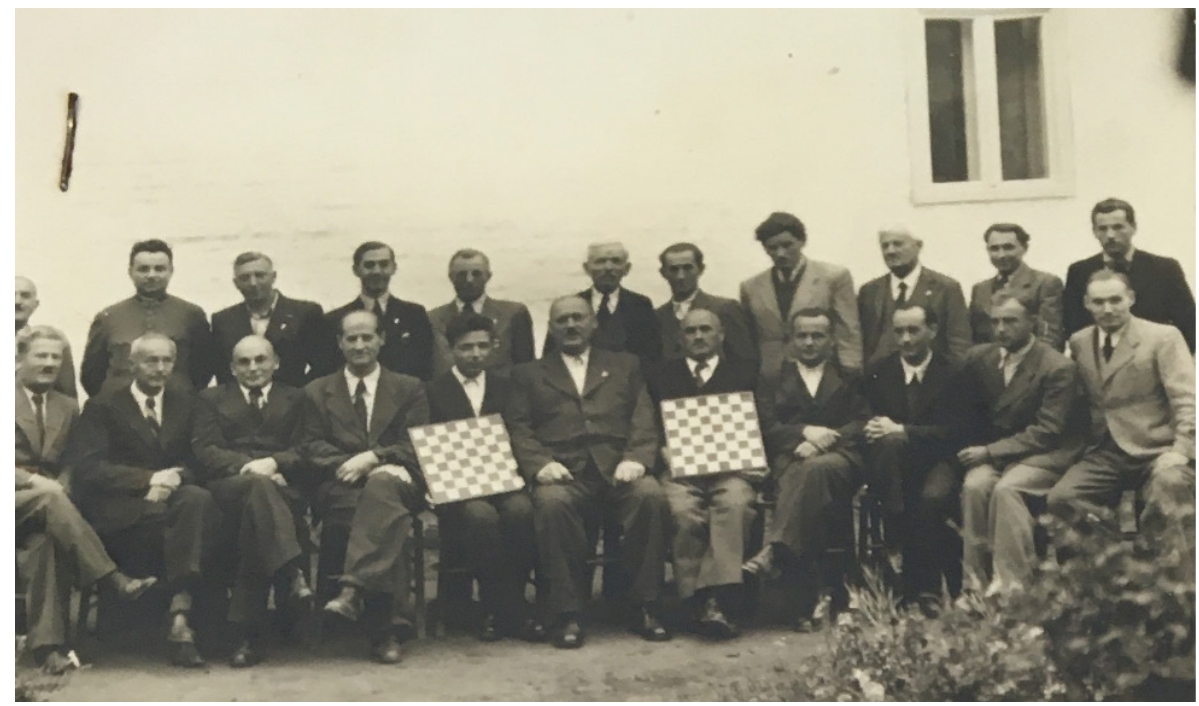

Ryc. 2. Uczestnicy turnieju szachowego, który odbył się 10 października 1943 r. w miejscowości Villány (źródło: CAW WBH, Uch. Pol. Węg., sygn. II.31.24., k. 3)

W wielu obozach zakładano orkiestry oraz chóry, które zapewniały oprawę muzyczną mszy oraz występowały podczas różnych uroczystości. Polscy uchodźcy, w większości w miejscach internowania dla oficerów, zakładali lokalne gazetki obozowe oraz pisali kroniki, które zachowały się do dziś.

\section{Relacje}

Oczywistym skutkiem istnienia polskich obozów wojskowych i przebywania Polaków na Węgrzech było nawiązanie relacji z miejscową ludnością. Według wspomnień świadków często przeradzały się one w przyjaźnie. Warto zaznaczyć, że Węgrzy, w szczególności na początku wojny, bardzo wspierali Polaków. W lokalnej prasie pojawiały się artykuły nawołujące do pomocy Polakom oraz informujące o ich losie, m.in. w gazecie „Zalai Közlöny”, wydawanej w Nagykanizsy $^{81}$. Węgrzy przekazywali dary, oferowali nocleg, dzielili się jedzeniem czy ubraniami. Potwierdzają to wspomnienia Aliny Wasilewskiej - córki jednego z polskich oficerów, która trafiła do obozu dla internowanych żołnierzy w Eger. Opisała ona ludność węgierską przerzucającą przez mury obozu paczki

\footnotetext{
81 K. ŁuвCZYк, G. ŁUвCZYк, op. cit., t. 2, s. 53.
} 
z żywnością i ubraniami dla Polaków. Obóz w Eger był placówką zamkniętą i władze obozowe niechętnie wydawały przepustki, w związku z czym Polacy nie mieli nawet możliwości osobistego podziękowania darczyńcom. Warto dodać, że Polacy, gdy mieli taką możliwość, także starali się pomagać Węgrom, m.in. kiedy w maju 1940 r. w Vámosmikoli była ogromna powódź, orkiestra obozowa zorganizowała koncert, a dochód z biletów przeznaczyła na pomoc powodzianom. Zdarzało się, że polscy lekarze leczyli za darmo Węgrów, np. w Siklós i Nagykanizsa, lub uczyli ich języków obcych.

Nie we wszystkich obozach i miejscowościach relacje polsko-węgierskie były braterskie. W wielu wspomnieniach osoby negatywnie nastawione do Polaków określano mianem „hitlerowców”. Przypisywano im proniemieckie sympatie. Do spięć pomiędzy żołnierzami a Węgrami dochodziło na różnych płaszczyznach, m.in. w pracy - gdy wywiązał się konflikt pomiędzy pracodawcą a zatrudnionym, czy w obozie - pomiędzy Polakami a władzami obozowymi i strażnikami.

\section{Podsumowanie}

Obecność polskich uchodźców w czasie II wojny światowej niewątpliwie wpłynęła na funkcjonowanie węgierskich miast i wsi. Węgrzy mieli większy rynek zbytu, możliwość zatrudniania Polaków oraz zysk z wynajmowanych im mieszkań czy pokoi. Wydarzenia kulturalne przyczyniały się natomiast do zacieśniania relacji pomiędzy uchodźcami i lokalną ludnością.

Przez pierwsze dwa lata wojny liczba polskich uchodźców zdecydowanie malała, co miało związek z prowadzoną akcją ewakuacyjną. Przyczyniało się to także do zmian w rozmieszczeniu obozów, jesienią 1939 r. było ich bowiem ok. 140, w 1941 r. ich liczba zmniejszyła się do ok. 30, a w 1944 r. do 21. Część ośrodków została zlikwidowana, część połączona ze sobą, a polscy uchodźcy byli zmuszeni do zmiany miejsca zamieszkania.

Obecność internowanych polskich żołnierzy pozostawiła pewne ślady w węgierskich miastach i wsiach. Część ludności nauczyła się języka polskiego, niektórzy uchodźcy zdecydowali osiedlić się po wojnie na Węgrzech na stałe. O obecności Polaków świadczą też pamiątki materialne - tablice pamiątkowe oraz dary przekazywane przez uchodźców lokalnej społeczności lub 
kościołowi. Po wydarzeniach tamtych lat pozostały także spisane wspomnienia świadków.

Cezurą końcową losów polskich uchodźców wojskowych podczas II wojny światowej jest 19 marca 1944 r., czyli data agresji III Rzeszy na Węgry. Działalność instytucji wspierających polskich żołnierzy została uniemożliwiona ${ }^{82}$. Aresztowano najważniejsze osoby związane z pomocą uchodźcom - Józsefa Antalla oraz płk. Lóránda Uttasyego, pełniącego funkcję szefa XXI Oddziału Ministerstwa Honwedów. Aby zapewnić uchodźcom wojskowym względne bezpieczeństwo, starano znaleźć się im pracę w rolnictwie ${ }^{83}$. Straszny los spotkał żołnierzy pochodzenia żydowskiego. Zostali oni zgromadzeni w specjalnie utworzonym podobozie w Vámosmikola (łącznie 279 osób), a następnie wywiezieni do obozów koncentracyjnych ${ }^{84}$. Na wniosek władz niemieckich uchodźcy byli stopniowo kierowani w kierunku granicy z Austrią, aby następnie trafić do obozów pracy w Niemczech. Nawiązując do tytułu niniejszego artykułu, w 1944 r. znowu wielu „bezdomnych, lecz drogich” Polaków starało się znaleźć schronienie wśród zaprzyjaźnionych Węgrów, a niektórzy z nich ponownie udzielili im pomocy.

\section{BIBLIOGRAFIA}

\section{Źródła archiwalne}

\section{Archiwum Akt Nowych}

Organizacje pomocy Polakom i instytucje polskie na Węgrzech, Amerykańska Komisja Pomocy Polakom na Węgrzech, sygn. III/12, III/27, III/81.

\section{Archiwum Związku Nauczycielstwa Polskiego}

Komisja do Badania Dziejów Oświaty i Wychowania, sygn. 127,140.

\section{Centralne Archiwum Wojskowe, Wojskowe Biuro Historyczne w Warszawie}

Uchodźstwo polskie na Węgrzech, sygn. II.31.18, II.31.24, II.31.28, II.31.31, II.31.32, II.31.34.

\footnotetext{
82 I. LAGZI, Uchodźcy polscy..., s. 278.

83 Ibidem, s. 197.

${ }^{84}$ Ibidem, s. 199.
} 


\section{Źródła drukowane}

Wspomnienia polskich uchodźców na Wegrzech w latach 1939-1945, red. J. Stolarski, Warszawa 1999.

\section{Prasa}

„Nasze Życie - czasopismo żołnierzy polskich internowanych w Królestwie Węgier” 1941.

\section{Opracowania}

Csorba H., Csorba T., Ziemia wegierska azylem Polaków: 1939-1945, Warszawa 1985.

Kapronczay K., Refugees in Hungary: Shelter from Storm During World War II, Toronto-Buffalo 1999.

Kopyś T., Polityka zagraniczna Wegier w latach 1867-1945, Kraków 2018.

Lagzi I., Droga żotnierza polskiego przez wegierska granice w latach 1939-1941, Poznań 1987.

Lagzi I., Uchodźcy polscy na Wegrzech w latach II wojny światowej, Warszawa 1980.

Łubczyk K., Łubczyk G., Pamięć: polscy uchodźcy na Wegrzech 1939-1946, t. 1-2, Warszawa 2012.

Majka J., Internowanie 10. Brygady Kawalerii (zmotoryzowanej) na Wegrzech w 1939 roku, „Annales Universitatis Mariae Curie-Skłodowska. Sectio F” 2005, t. 60, s. 183-191.

Roman W.K., Ewakuacja i internowanie wojsk polskich we wrześniu 1939 roku, „Piotrkowskie Zeszyty Historyczne” 2004, t. 6, s. 155-173.

Stasierski K., Polscy uchodźcy na Wegrzech w latach 1939-1945, „Przegląd Historyczny” 1961, t. 52, nr 2, s. 247-273.

Śladami rodaków: groby polskich uchodźców wojennych na wegierskich cmentarzach 19391945, red. B. Bogdańska-Szadai i A. Szalai, Budapeszt 2009.

Wieliczko M., Polacy na Wegrzech, Lublin 1977.

Woźniakowski K., W kregużycia kulturalnego polskiego wojennego uchodźstwa na Wegrzech 1939-1945. Studia i szkice, Kraków 2018. 


\title{
Barbara Łochowska
}

\section{„WELCOME HOMELESS, BUT DEAR BROTHERS”. POLISH MILITARY CAMPS IN HUNGARY DURING WORLD WAR II}

\begin{abstract}
Summary. After the Soviet aggression against Poland in September 1939, the area of the Kingdom of Hungary became the destination for the evacuation of many Polish soldiers. In 1939, despite the cooperation between Hungary and the Third Reich, the citizens of this country made a great effort to help Poles. In the fall of 1939, over 45000 Polish soldiers were deployed in approximately 140 camps. Most of the camps were established in urban and rural centers, which significantly influenced the appearance as well as the organizational and population structure of towns and villages. Considering the number of civilian refugees, such a large group of the Polish population was a real challenge for the Hungarian authorities in terms of relocating Poles and taking care of them.

The issues raised in the article concern the organization of Polish camps for interned soldiers in the Kingdom of Hungary. It describes the impact of the existence of these centers on the functioning of towns and villages, the population living in them, as well as on Poles themselves, from the perspective of whom staying in Hungary was supposed to be a temporary solution.
\end{abstract}

Keywords: refugees, Poles in Hungary, internment, military camps, World War II 